\title{
HEGELOVA SPEKULACE JAKO ODPOVĚĎ NA PLATÓNOVU DIALEKTIKU
}

\section{Tereza Matějčková}

\section{Úvod}

„Vše, co nás obklopuje, může být pojato jako svědectví dialektična, “1 poznamenává Hegel v Encyklopedii filosofických věd. Takto velkoryse uchopená dialektika vzbuzovala již v Hegelově době nedůvěru. Při slově „dialektika“" se současníkům vybavilo v první řadě pojetí dialektiky jako „logiky klamu“, tak jak ji podal Kant v Kritice čistého rozumu. Z této interpretace nicméně vychází i Hegel, dokonce ji považuje za jeden z nejzáslužnějších aspektů Kantova díla vůbec: Oceňoval v první řadě objev, že se právě jako rozumné bytosti nevyhnutelně zaplétáme do rozporů a antinomií, které nejsou - jak čteme v Kritice čistého rozumu trikem „nějakého sofisty“, 2 ale které náleží k bytnosti lidského rozumu.

Ihned je však třeba upřesnit, že Hegelův přístup ke Kantově dialektice byl podvratný. Zatímco Kant tvrdil, že se rozum nutně zaplétá do sporu, jakmile se odpoutává od smyslové zkušenosti, Hegel toto omezení přešel, niternou spornost připsal rozumu vůbec, a navíc nově interpretoval rozum, který nechápe v první řadě jako lidskou mohutnost, ale jako základní strukturu skutečnosti, jejíž dynamiku by pak tvořila právě dialektika. ${ }^{3}$ Po takovém interpretačním zásahu nezůstal z Kantovy koncepce kámen na kameni.

1 G. W. F. Hegel, Enzyklopädie der philosophischen Wissenschaften, I, in: týž, Werke, vyd. E. Moldenhauer-K. M. Michel, VIII, Frankfurt a. M. 1986, § 81, str. 174.

2 I. Kant, Kritik der reinen Vernunft, in: týž, Werke, III, Ausgabe der Preußischen Akademie der Wissenschaften, Berlin 1900 nn., A 298.

3 Tento překrok vystihl Milan Sobotka, když poznamenává, že „optika dialektiky není už optikou lidské konečné pozice ve světě, nýbrž ztotožněním s optikou bytí samého“. M. Sobotka, Člověk, práce a sebevědomí, Praha 1969, str. 81. Dále se Hegelově pojmu dialektiky - mimo jiné i ve vztahu ke Kantovi a Fichtovi - zevrubně věnuje Jindřich Karásek (Metoda jako sebevztah pojmu. K Hegelovu pojetí dialektické metody, in: Filosofický časopis, 61, 2013, str. 681-704). S interpretacemi významných badatelů jako Henricha, Fuldy či Gadamera se český čtenář může seznámit ve sborníku J. Chotaš - J. Karásek (vyd.), Hegelova dialektika, Praha 2007. 
Pozoruhodná je cesta, na níž Hegel k této reinterpretaci dospěl. Kantovo pojetí dialektiky bylo pro Hegela stěžejní proto, že navazovalo na motivy antické filosofie. Ač toto propojení vposled podle Hegela úspěšné nebylo, jedná se o postup, kterého je třeba se držet: Moderní filosofie je totiž ohrožena subjektivismem, ${ }^{4}$ případně antropocentrismem, a právě antické myšlení skýtá možnosti, jak se tomuto nebezpečí vyhnout. Hegel si všímá, že si toho byl vědom - s ohledem na konkrétní motivy - i Kant, o čemž svědčí především jeho úvahy o účelu, v nichž - alespoň hermeneuticky - umist'uje původ smyslu nikoli výhradně do subjektu, ale rovněž do organismu, a v nichž za své východisko pojímá aristotelskou koncepci účelu. ${ }^{5}$

Navzdory tomu, že Hegel zprvu vychází z Kanta, sahá záhy k Platónovým dialogům, v nichž objevuje předobraz dialektiky, a dokonce pořizuje vlastní překlad dialogu Sofistés. Hans-Georg Gadamer v této souvislosti poznamenává, že to byl Hegel, který pro německou filosofii objevil Platónovy „spekulativní“ dialogy, především Parmenida, Sofistu a Timaia. ${ }^{6}$ Martin Heidegger nebo Dieter Henrich pak hovoří o přelomových výkladech těchto dialogů a zdůrazňují jejich důležitost pro Hegelovo vlastní myšlení: První považuje Hegelovu filosofii za završení filosofie Platónovy, ${ }^{7}$ druhý má za to, že by Hegelova filosofie měla být interpretována spíše v tradici antického než novověkého myšlení ${ }^{8}$ a Hegelovu ontologii pak označuje výrazem „dynamizovaný platonismus“.9

4 Hegel hovoří o ,subjektivním idealismu“, v němž je lidský rozum pojat jako vládce nad světem, do něhož zvnějšku klade smysl. Viz např̀. G. W. F. Hegel, Fenomenologie ducha, přel. J. Patočka, Praha 1960, str. 183 n.

$5 \quad$ Srv. I. Kant, Kritik der Urteilskraft, in: týž, Werke, V, Ausgabe der Preußischen Akademie der Wissenschaften, str. 304, 317, 352, 357-363, 374. K Hegelovu ocenění Kantova pojetí účelu viz G. W. F. Hegel, Vorlesungen über die Philosophie der Religion. Einleitung. Der Begriff der Religion, I, vyd. W. Jaeschke, Hamburg 1993, str. 320. Ke srovnání kantovského a aristotelského pojetí účelu viz rovněž G. W. F. Hegel, Fenomenologie ducha, str. 193-203.

6 H.-G. Gadamer, Hegel und die antike Dialektik, in: týž, Neuere Philosophie: Hegel, Husserl, Heidegger (Gesammelte Werke, III), Tübingen 1987, str. 4.

7 M. Heidegger, Hegel und die Griechen, in: týž, Wegmarken, in: Gesamtausgabe, IX, Frankfurt a. M. 1976, str. 427-444.

8 D. Henrich, Erkundung im Zugzwang. Ursprung, Leistung und Grenzen von Hegels Denken des Absoluten, in: W. Welsch - K. Vieweg (vyd.), Das Interesse des Denkens. Hegel aus heutiger Sicht, München 2003, str. 9-32.

9 D. Henrich, Kant und Hegel, in: týž, Selbstverhältnisse. Gedanken und Auslegungen zu den Grundlagen der klassischen deutschen Philosophie, Stuttgart 2001, str. 190. 
Podobné zhodnocení však není beze zbytku přesvědčivé. Originalita Hegelova díla tkví právě v tom, že sice pojímá antickou filosofii jako zdroj mnohých motivů, které však uchopuje vždy na pozadí novověkého myšlení. V jistém smyslu pak Hegel překračuje antické myšlení - svým navázáním na novověké filosofy - i novověkou filosofii, do níž vnáší motivy antické provenience.

Zmíněné sepětí antického a novověkého myšlení má být předmětem této stati. Zaměřím se především na souvislost dialektiky a novověkého převrácení vztahu ideje a jevu: Nejsou to ideje, které by byly nejdokonaleji poznatelné, poznatelný je jedině jev, a to nikoli navzdory, ale díky jeho bytostné nestálosti. Při našich úvahách se budeme vztahovat převážně k Platónovu dialogu Sofistés. Ačkoli Hegel ve Fenomenologii ducha zmiňuje dialog Parmenidés, který nazývá „snad největší[m] dí$1[\mathrm{em}]$ umění starověké dialektiky“ ${ }^{10}{ }^{10}$ zůstává pro něj svědectvím pouze dialektiky negativní. Vlastní filosofii ale pojímá Hegel jako „pozitivní dialektiku“ - a tu formuluje Platón v dialogu Sofistés, který se tím stává výrazným inspiračním zdrojem pro Hegelovu filosofii vůbec.

\section{Dialektika jako vztah, rozmluva a „cesta“}

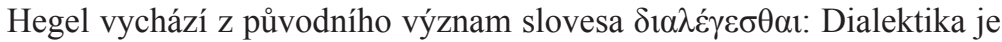
řeč bytostně vázaná na ono „mezi““ ( $\delta$ ió), a řeč je tak možná jen tam, kde se ustavuje vztah, tedy tam, kde je prítomen druhý. Dialektiku je pak třeba blíže určit jako správné zacházení s řečí a v tomto smyslu je metodou čili cestou, na níž se člověk dobírá pravdy. ${ }^{11}$ I výraz „metoda“ přejímá Hegel v původním smyslu slova: Jedná se o cestu, dokonce o cestu, kterou lze, jak čteme ve Fenomenologii ducha, označit za cestu ,pochybnosti nebo ve vlastnějším smyslu za cestu zoufání“, 12 cestu „skepticismu, který se naplňuje“. ${ }^{13}$ Hegelovy výroky o zoufání, obavě, ${ }^{14}$ nedůvěře, ${ }^{15}$ bolesti ze ztráty pravdy ${ }^{16}$ či avizovaném násilí, které vědomí

\footnotetext{
10 G. W. F. Hegel, Fenomenologie ducha, str. 90.

11 K souvislosti řeči, metody a vědy či pravdy viz G. W. F. Hegel, Enzyklopädie der philosophischen Wissenschaften, I, § 81, str. 172-179.

12 G. W. F. Hegel, Fenomenologie ducha, str. 98.

13 Tamt.

14 Tamt., str. 96.

15 Tamt.

16 Tamt., str. 98.
} 
podstupuje, ${ }^{17}$ nesvědčí o přepjaté expresivitě, ale o snaze dostát dialogičnosti filosofie v tom smyslu, že vědomí (a spolu s ním čtenár Fenomenologie ducha) musí na tuto cestu přistoupit, zakusit ji na sobě a v sobě nahlédnout: nezdůvodněná a nepochopená pravda totiž není pravdou. Lze proto tvrdit, že Hegel navazuje na Platóna, nakolik pojímá dialektiku jako metodu svázanou s dialogem a spějící skrze tento dialog k pravdě. ${ }^{18}$

V této souvislosti je příznačné, že Hegel připisuje řeči hned ve dvojím smyslu atributy „božství“: ${ }^{19}$ Za prvé je řeč prostředkem, jak se osvobodit od jednotlivosti, na níž původně ulpíváme, a jak tudíž vstoupit do světa idejí, a za druhé nahlížíme díky jazyku samu bytnost skutečnosti. Jazyk totiž pro Hegela není médiem, v němž si svět či skutečnost konstruujeme, ale je nejhlubší reflexí bytí vůbec. ${ }^{20}$

Zde se již setkáváme s Hegelovým spekulativním krokem (či přímo skokem), při němž si vypomáhá Platónovou dialektikou: Bytí má konkrétní strukturu, která se vyznačuje vztahem stejnosti a jinakosti; samo bytí je sebevztahem v tom smyslu, že jsoucno je jen, pokud se jeví, a jev je, jak dále uvidíme, vztahem stejnosti a jinakosti. Náš jazyk je pak reflexí této duchovnosti, která je bytí vlastní, a v tomto smyslu jej Hegel nazývá „spekulativním duchem“:21 V jazyce přichází ke slovu bytnost skutečnosti, aniž by jazyk skutečnost vytvářel.

Tento krok se vyznačuje specifickým sepětím antického dědictví a novověké filosofie. Hegel se opírá o myšlenku obecnin, které původně formulujeme právě v jazyce, přičemž nám tyto struktury umožňují objevovat podstatu skutečnosti. Těmto obecným strukturám přitom připisuje větší důležitost než Fichte, ale i další myslitelé tradice, kteří lidskou subjektivitu do značné míry vystihují reflexivitou, a nikoli schopností myslet obecniny.

Že jsou tyto obecné struktury či ideje pro člověka tak stěžejní, však neznamená, že by jejich prostřednictvím měla být ontologicky ponížena

17 Tamt., str. 99. K násilí srv. rovněž tamt., str. 30.

18 Např. Platón, Resp. $511 \mathrm{nn}$.

19 G. W. F. Hegel, Fenomenologie ducha, str. 112. Srv. rovněž tamt., str. 107.

20 Že je Hegelova spekulace bytostně spjata s odmítnutím výhradního nároku člověka na bytí, poznamenává Milan Sobotka: „Hegel však není filosofem člověka jako nositele smyslu, který by vnášel do smysluprostého univerza, člověk je naopak díky své dějinnosti naplňovatelem kosmického smyslu.“" M. Sobotka, Patočkova prednáška z r. 1949 o Hegelově Fenomenologii ducha, in: Filosofický časopis, 45, 1997, str. 851.

21 G. W. F. Hegel, Wissenschaft der Logik, I, in: E. Moldenhauer - K. M. Michel (vyd.), Werkausgabe in 20 Bänden, V, Frankfurt a. M. 1969 nn., str. 10. 
smyslová skutečnost či bezprostřední přítomný svět. Hegel právě naopak definuje novověkou filosofii - a paradoxně idealismus především - „zájmem“ o sdílený i smyslový svět: Tato filosofie nespěje k vystavování paralelních světů, ale nalezení idejí v př́itomném světě, a tudíž rovněž k povýšení přítomného světa, ${ }^{22}$ a Hegelovu filosofii lze považovat za nejzazší vyjádření tohoto pokusu: Ve světě je odhalena sféra „logična“, která nepřináleží ani objektivitě, ani subjektivitě, která spíše oba tyto hegelovsky řečeno - ,abstraktní " pojmy podbíhá.

Svět smyslové skutečnosti tak není poté, co je objeven svět idejí, pojat jako ontologicky méněcenný, ideje jsou naopak formulovány proto, aby bylo možné porozumět př́tomnému světu. V tomto smyslu nejsou ideje nejvyšším stanovištěm, k němuž filosof dospívá. Cesta je završena až poté, co filosof dosvědčí, že se jeho schopnost nevyčerpává v pomyslném „výstupu“, ke kterému Hegel poskytuje „žebřík“. ${ }^{23}$ Filosofem je myslitel teprve tím, že se vrátí do světa - zde je jeho těžiště, a právě proto vyzývá Hegel na poslední úrovni Fenomenologie ducha, na úrovni absolutního vědění, že se vědomí, které dospělo $\mathrm{k}$ absolutnímu vědění, nyní má vrátit do bezprostřednosti, od níž se má nechat znovu ,vychovat". 24

Předpoklad, který Hegel přijímá jako reakci na neuspokojivost tzv. subjektivního idealismu, s nímž spojuje především Fichta, zní, že dialektika zrcadlí samu strukturu skutečnosti - a právě tento předpoklad lze považovat za vlastní jádro Hegelovy spekulace. Nyní je třeba zvážit, v jakém smyslu je skutečnost dialekticky ustavená, co to vlastně znamená a jak tato okolnost souvisí s Platónovou filosofií.

\section{Smyslovost, vnímání a jazyk}

Ve Fenomenologii ducha je vědomí na úrovni smyslové jistoty přesvědčeno o tom, že poznání je bytostně receptivní a jisté si je pouze tím, co zakouší tehdy, nechá-li na sebe pasivně působit bohatství smyslových vjemů. ${ }^{25} \mathrm{~V}$ kontextu našeho tématu je stěžejní, proč takováto koncepce

22 K souvislosti německého klasického idealismu a zájmu o svět viz např̀. G. W. F. Hegel, Fenomenologie ducha, str. 179-181; týž, Enzyklopädie der philosophischen Wissenschaften, III, in: Werkausgabe in 20 Bänden, X, vyd. E. Moldenhauer - K. M. Michel, Frankfurt a. M. 1969 nn., dodatek k § 393, str. 57-63.

23 G. W. F. Hegel, Fenomenologie ducha, str. 65.

24 Tamt., str. 487.

25 Tamt., str. 105. 
nemůže být $\mathrm{v}$ rámci Hegelova myšlení úspěšná. Vědomí je na této úrovni přesvědčeno, že pravdu bude schopno uchopit tehdy, nebude-li zasahovat do procesu vnímání, a bude-li tedy pasivní. Hegel však namítá, že i pasivita je výkonem, a tudíž ji nelze považovat za cosi neutrálního. Zastíráme-li si tuto skutečnost, tak jako si ji zastírá vědomí na první úrovni Fenomenologie ducha, nejsme schopni reflektovat vlastní stanovisko, které se nevyhnutelně otiskuje do našeho vztahu ke světu. První podoba vědomí se zcela odevzdává vlastní perspektivě právě tím, že ji nereflektuje. ${ }^{26}$

Toto sepětí nejzákladnějšího vědomí s vlastním (dokonce fyzickým) stanoviskem je ostatně jedním z důvodů, proč se jedná o „němou“ úroveň Fenomenologie ducha. Jazyk by do dané situace již vnesl zprostředkování, které poznávající na této úrovni nepovažuje za slučitelné s jistotou. Že se však na této úrovni nepracuje s jazykem, je pro Hegela znamením toho, že se vědomí ocitá na úrovni, na níž lze hovořit o jistotě, nikoli však o pravdě: To, co smyslové vědomí má za jisté, nemůže zdůvodnit, a právě schopnost zdůvodnit své stanovisko považuje Hegel za jednu z nutných podmínek pravdivosti.

Tato okolnost vyjevuje rovněž nepatřičnost obtíže, s níž se potýká vědomí na úrovni smyslovosti: Vědomí usiluje o dosažení objektivity, ke které má dospět tím, že si zakáže vstupovat do jevu, a bude tedy naprosto pasivní. Jenže pravda a perspektivnost jsou vzájemně spjaty. Pravda je vždy situovaná. Ale její další podmínkou je to, že vědomí své hledisko, z něhož formuluje pravdu, reflektuje, a pravda je tedy sepětím vlastní perspektivy a formulace „zákona“ této perspektivy, která rozevírá zaujaté stanovisko směrem k jiným možným náhledům.

Nezávisle na schopnosti jazyka tak sice mohu druhému ukázat, co míním, ale co již ukázat nemohu, je reflexe vlastního stanoviska. Sem musí vstoupit jazyk a jeho prostřednictvím argumentace, a Hegel tak nakonec bude tvrdit, že již i ukazování je podmíněno společným stanoviskem, na základě něhož teprve může druhý vědět, na co lze ukazovat a co lze ukazováním mínit. Než tedy mohu ukázat např. na strom, musí již být jasné, co je předmětná perspektiva, a tedy rovněž to, co ukazováním míníme, tedy to, zda ukazujeme např. na celý strom, na kůru či na listy. Hegel by tak řekl, že si nejprve musíme ujasnit „bytí o sobě“ daného předmětu, prričemž je však již zde patrné, že toto „o sobě“ není statická danost či úběžník, ale perspektiva, která se vyvíjí spolu s poznávajícím,

26 Tamt., str. 106-107. 
aniž by však skutečnost tohoto vývoje činila z tohoto „o sobě“ fenoménu něco nicotného.

Vědomí spočívající na stanovisku smyslové jistoty se vyznačuje obavou, že pozbyde své idiosynkratické stanovisko, jakmile ,přeloži“ jedinečnost hlediska do obecných pojmů, v nichž zanikne originální výkon vnímajícího. $\mathrm{V}$ tom případě však nemůže opřít to, co považuje za jistotu, o žádné důvody, a to ani před sebou, ale především ne před druhými. Takto pojaté smyslové poznání je tedy nedostatečné především z důvodu jeho ,nedialogičnosti““.

Již z tohoto zjištění plyne několik obecných závěrů o Hegelově teorii pravdivosti: Pravda musí být intersubjektivně verifikovatelná, a je tedy vždy bud' explicitně sdílená, nebo alespoň sdělitelná. Jazyk je pak první zkouškou, která vyjeví, zda jsou př́slušné jistoty konsistentní a zda mohou být druhému vykázány. Již proto je řeč základnějším stanoviskem než bezprostřední vnímání smyslových fenoménů: Jazyk totiž svazuje vědomí s hlediskem druhého, resp. druhých, a teprve na pozadí společného - a to pro Hegela znamená i obecného - základu, kterým je řeč, se může vyjevit pluralita stanovisek.

Vědomí je navíc jazykem přinuceno, aby vnímalo určitým způsobem - aby vneslo do svého vnímání řád a aby skrze obecné kategorie zadrželo uplývající proud smyslových vněmů, resp. aby rezignovalo na bezprostřední jedinečnost, s níž původně spojuje „nekonečné bohatství“, 27 jež se však ve skutečnosti vyjevuje jako měna, která je „falešná“, nebot' nemůže být sdílena. Má-li vědomí skutečně vnímat a myslet, musí se vzdát tohoto lpění na vlastní perspektivě a „pozastavit“ její platnost, resp. vlastní bezprostřední stanovisko zrušit (aufheben). To však neznamená, že by se tato konkrétní perspektiva a s ní spjaté bezprostřední vnímání staly zcela irelevantními. Zmíněné „zrušení“ v této souvislosti znamená, že je dané stanovisko včleněno do širší perspektivy. Jen z tohoto hlediska se v jazyce odehrává zánik (das Zugrundegehen) nestálého smyslového světa, čímž Hegel prrirozeně nemíní, že by tento svět pro vědomí zmizel nebo přestal být podstatný. Hegel se orientuje na původní význam výrazu „,zu Grunde gehen“: Bezprostředně smyslový svět nezaniká, ale vrací se ke svému původu (Grund).

Než se blíže podíváme na tento „původ“, můžeme říct, že „zánik“ probouzí vědomí ke kvalitativně novému bytí: „Chaotický proud“ smyslového vědomí se mocí „božské povahy“ 28 jazyka projasňuje v „logický“

27 Tamt., str. 105.

28 Tamt., str. 112. 
pohyb, jímž je vědomí neseno. Díky jazyku je vědomí začleněno do rámce, který jednotlivé vědomí překračuje, čímž mu skýtá cíl. Tímto cílem je nárok formulovat pravdu. Protože je jazyk podmínkou tohoto hledání, proměňuje se dosud pouze mínící vědomí (das meinende Bewusstsein) ve vědomí, které je schopno vnímat, přičemž vnímání, „das Wahr-nehmen“, je pro vědomí bytostně spjato se schopností formulovat verifikovatelné teze. Jazyk tak vyprovází vědomí zmítající se v bezprostředně nezacíleném pohybu na cestu, na níž transcenduje svou mínící jednotlivost a která spěje na úroveň označovanou jako ,absolutní vědění“.

Jazyk se však nevyčerpává ve schopnosti odstoupit od bezprostředního stanoviska a rovněž není teprve sekundárním dotvořením smyslového vnímání, ale postihuje na smyslovém předmětu samém cosi bytostného. Jazyk je tak spjat se smyslově vnímatelným bytím, nebot' odhaluje struktury smyslovosti; je vyjádřením vlastní povahy bytí: Již ve smyslovém vnímání tkví jakýsi němý jazyk, který je strukturou bytí.

Předpoklad smysluplnosti, v níž se vědomí již vždy nachází, zakládá lidské chápání. Hegel tuto přítomnost smyslu, která se nevyčerpává naším výkonem, ${ }^{29}$ opakovaně kontrastuje s koncepcemi „subjektivních idealistů“, především s Fichtovým pojetím poznání, v němž jsou struktury bytí včleněny do struktur vědomí do té míry, že se vnějšek jeví jako konstrukce nitra. ${ }^{30}$ Hegel se chce právě takovéto koncepci vztahu člověka a světa vyhnout, mimo jiné tím, že proti Kantovi i Fichtovi opakuje, že člověk zde není od toho, aby bytí předepisoval, jak má být, nebo aby do bytí vkládal zákony, a to podle Hegela již proto, že kdyby tomu tak bylo a člověk by byl původně skutečně konfrontován s neurčitým, „smyslupustým“ světem, nemohl by vůbec vnímat, nebot' neurčitost není vnímatelná, a zákony, které by kladl do světa, by byly výsledkem libovůle. ${ }^{31}$

29 Hegel se v tomto smyslu vyjadřuje v úvodu k Fenomenologii ducha, v němž zaznívá, že podmínkou toho, abychom byli schopni myslet a vnímat, je přítomnost absolutna. G. W. F. Hegel, Fenomenologie ducha, str. 96.

30 K této souvislosti viz např. W. Marx, Hegels Phänomenologie des Geistes. Die Bestimmung ihrer Idee in ,Vorrede“ und „Einleitung“, Frankfurt a. M. 1971, str. 18.

31 Sám Fichte tuto obtíž řeší tím, že vztah člověka ke světu založí na primátu praktična a ve svém pojednání Die Bestimmung des Menschen, na něž se v hojné míře Hegel odvolával, tvrdí, že kdyby bylo poznání primární mohutností člověka, celý svět by se propadl do nicoty. J. G. Fichte, Die Bestimmung des Menschen, in: Gesamtausgabe der Bayerischen Akademie der Wissenschaften, vyd. R. Lauth H. Gliwitzky, I, 6, Stuttgart-Bad Cannstatt 1981, str. 246. 
Z fenomenologického hlediska zakoušíme vnímání jinak: Věci na nás doléhají vlastní silou, a tím si nás podmaňují. Vědomí tedy nevnáší řád a smysl do původně smysluprosté skutečnosti, ale učí se vnímat a myslet tím, že naopak nachází struktury sebe samého ve světě a tyto struktury považuje za odvozené ze světa, nikoli ze sebe. Výkon vnímání a myšlení - anebo obecně schopnost být přítomen světu, a tedy nebýt ponořen $\mathrm{v}$ „noc svého sebevědomi“",32 o níž Hegel hovoří na poslední úrovni Fenomenologie ducha - se daří jen tehdy, je-li vnímání a myšlení pozorností, která tkví v „,negaci sebeuplatnění a v odevzdání sebe sama věci“. ${ }^{33}$ Stěžejní však nyní bude otázka, co to vlastně pro Hegela je ona věc, jíž se máme odevzdat. V této souvislosti se rovněž vrátíme k výše zmíněnému ,původu“, do něhož se smyslové vnímání - „oklikou“ přes řeč - „navrací“.

\section{Jednota a mnohost ve vnímání}

Že jsme již před výkonem vnímání zahrnuti do struktur ve světě, je myšlenka, která Hegelovo dílo prostupuje. Hegel tím vyjadřuje nejen kritické stanovisko k Fichtově koncepci poznání, ale rovněž absolutního Já, které je určeno jako nejzákladnější jednota, $z$ níž vše další jako poznané povstává, a stejně tak odmítá i Schellingovu koncepci absolutna, které je definováno jako v sobě identická jednota. Proti tomu namítá Hegel, že upřednostňovat jednotu př̌d mnohostí je filosoficky neospravedlnitelné: To, že nemůžeme nezávisle na různosti vědět, co je jednota, vypovídá o bytostné vlastnosti jednoty samé.

Neznamená to ale, že by vědomí mělo na formulaci jednot rezignovat - schopnost formulovat jednoty je podmínkou každého myšlení, které činí rozdíly právě tím, že usouvztažňuje, tedy sjednocuje, konkrétní momenty fenoménu, aby je následně kladlo do opozice vůči jiným momentům. Problém nastává tehdy, je-li jednota povýšena na ontologicky radikálně vy̌šsí princip než mnohost. Ilustrací dialektiky mnohosti

32 G. W. F. Hegel, Fenomenologie ducha, str. 487.

33 G. W. F. Hegel, Enzyklopädie der philosophischen Wissenschaften, III, § 448, str. 250. Na tento motiv Hegelovy fenomenologické metody navazuje Jan Patočka, když tvrdí, že Hegel vyzývá vědomí: „Dívej se, rozebírej, sleduj struktury a pohyb - ale neplet' se do toho! Vymaž se, nikdo se nezajímá o to, co ty tomu řekneš! To není jen morálka filosofické skromnosti; znamená to, že filosof nemá provádět tezi toho, co se mu jeví před očima." J. Patočka, Úvod do fenomenologické filosofie, Praha 2003, str. $51 \mathrm{n}$. 
a jednoty je právě i úroveň vnímajícího vědomí ve Fenomenologii $d u$ cha: Vědomí zde formuluje pojem „vylučujícího Jedna“ na straně jedné, a množství obecných vlastností, které jsou této jednotě připisovány, na straně druhé. Sama věc se tedy jeví ze dvou protikladných perspektiv. Na straně jedné je to jednotný předmět (Hegel užívá příklad soli), ${ }^{34}$ v němž zanikají vlastnosti, na straně druhé je to mnohost - „médium“ - vlastností (daný předmět je slaný, krychlový, bílý), v níž zaniká jednota. Ale i v této mnohosti se nám opět ustavují jednoty, nebot' mnohost je ,společenství" 35 jednot ( $\mathrm{tj}$. mnohost je suma bělosti, slanosti, krychlovosti atd.). Samy vlastnosti tedy disponují „pevností“ a jednota nebo „soběrovnost" jim náleží stejně jako jednotlivému předmětu nebo věci a rovněž Já vykazuje specifickou soběrovnost. Každý fenomén - tedy rovněž věc jakožto vnímaná - tak uchovává a „střeží svou vlastní vylučující jednotu. Takováto rovnost se sebou samým musí náležet všemu, co je, a „kritérium pravdy jest tedy rovnost sobě, a jeho počínání je v tom, že pojímám vše, co je mu předmětem, jako sobě rovné“. 36

Protože Hegel ve stejné době, v níž pracuje na Fenomenologii ducha, přednáší $\mathrm{k}$ dějinám filosofie, především $\mathrm{k}$ motivům antického myšlení, interpretují četní badatelé př́slušné pasáže i jako komentář k tradičním otázkám teorie poznání na pozadí antického myšlení. Wolfgang Wieland v této souvislosti dokonce poznamenává, že „to, co se odehrává na začátku Hegelovy Fenomenologie, se v mnoha ohledech jen málo liší od toho, co v raných Platónových dialozích působí protreptika a elenktika. Můžeme tedy vycházet z hypotézy, že Hegelovu dialektiku smyslové jistoty lze chápat analogicky k této raně platónské dialektice, pro kterou jsou nezbytní - přinejmenším - dva partneři““.37 Tato spř́zněnost netkví jen ve formální, ale i v obsahové stránce: Vě-

34 G. W. F. Hegel, Fenomenologie ducha, str. 117.

35 Tamt., str. 116.

36 Tamt. Srv. v této souvislosti pasáž ze Sofisty, v níž se tvrdí, že tam, kde není

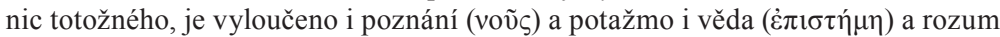
(

37 W. Wieland, Hegelova dialektika smyslové jistoty, přel. M. Petř́iček, in: J. Chotaš - J. Karásek (vyd.), Hegelova dialektika, str. 76. Patrně prvním, kdo upozornil na okolnost, že se Hegel na úrovni vědomí soustavně zabývá pozicemi traktovanými v klasických antických dílech, byl W. Purpus, který v roce 1908 publikoval stat' Zur Dialektik des Bewußtseins nach Hegel. Ein Beitrag zur Würdigung der Phänomenologie des Geistes, Berlin 1908. O toto pojednání se opírá rovněž Martin Heidegger ve své přednášce o Fenomenologii ducha (in: Gesamtausgabe, XXXII, Frankfurt a. M. 1980, str. 58). 
domí dospívá na této úrovni vývoje $\mathrm{k}$ pozici, kterou lze v návaznosti na Parmenida z Eleje označit jako „eleatskou“. ${ }^{38}$ Hegel připisuje Parmenidovi dualistické rozlišení na bytí, které je jednotou prostou vší různosti, a nebytí, které nikterak není, a proto nemůže být myšleno; následně je bytí - v Hegelově interpretaci Parmenida - pojato jako jediná „velká afirmace". 39

Vědomí zastávající „eleatskou“ pozici tak považuje za jsoucí jen to, co je naprosto „sobě rovné“, resp. to, co vykazuje jednotu, jež ze sebe vylučuje jinakost. Za tuto naprostou rovnost jsou označeny obecné pojmy, které jsou pravdou nestálých jevů. Výlučně těmto obecným, a proto nepomíjejícím pojmům je připsáno bytí, nikoli konkrétnímu jednotlivému předmětu. Hegel tak na této úrovni formuluje obecné pojmy, které se vyznačují tím, že jsou naprosto tím, čím jsou, a tím na ně vztahuje strukturu parmenidovského bytí. Tato interpretace je následně včleněna do Hegelova porozumění Platónových obecnin: ${ }^{40}$ Běloba, kterou se vyznačuje sůl, není ničím jiným než bělobou.

Jakmile Hegel tuto pozici vylíčí, ihned přechází ke kritice, a př́slušné pasáže můžeme následně číst jako variaci na Platónovu kritiku parmenidovské pozice v dialogu Sofistés. Paralelní krok přitom sledujeme v Hegelově pojetí vnímání, tak jak je předloženo v Encyklopedii filosofických věd, která je sepsána v době, v níž se Hegel Platónovým dialogem Sofistés zabýval nejintenzivněji. Protějškem této obecné soběrovnosti je v $S o$ fistovi rod totožnosti, která však není jen totožností, nebot' je bytostně určena svým vztahem k různosti. Tato totožnost je zároveň podmínkou bytí jednotlivých rodů, neboli jednotlivé rody musí vykazovat základní identitu. Eleatikovi je v tomto smyslu dáno zapravdu, a ani Hegel se „otcovraždy“ nedopouští: Že je jsoucí jedním, je podmínkou existence a rovněž myslitelnosti; ${ }^{41}$ a Hegel pak považuje základní, byt' v tomto

38 Souvislost této úrovně Fenomenologie ducha s Parmenidovým pojetím bytí a nebytí vysvítá rovněž z toho, že se Hegel vztahuje k této úrovni Fenomenologie ducha na počátku Logiky jako vědy, kde se Parmenidem explicitně zabývá. Viz G. W. F. Hegel, Wissenschaft der Logik, I, str. 84-111. K této souvislosti viz R. W. Meyer, Dialektik der sinnlichen Gewißheit und der Anfang der Seinslogik, in: M. Riedel, Hegel und die antike Dialektik, Frankfurt a. M. 1990, str. 244-267.

39 G. W. F. Hegel, Vorlesungen über die Geschichte der Philosophie, I, in: E. Moldenhauer - K. M. Michel (vyd.), Werkausgabe in 20 Bänden, XVIII, Frankfurt a. M. 1969 nn., str. 289 n.

$40 \mathrm{~K}$ této souvislosti viz H.-G. Gadamer, Hegel und die antike Dialektik, str. 3-28.

41 Platón, Soph. 254e. 
smyslu abstraktní rozlišení na bytí a nebytí za počátek vší filosofie, resp. myšlení samého. ${ }^{42}$ Tato soběrovnost však není jedinou podmínkou myšlení ani bytí, a proto u ní nelze bez dalšího setrvat: Totožnost nelze uchopit nezávisle na jinakosti, nebot' čisté bytí, které postrádá rozlišení a které se nevztahuje k jinému, nemůže být myšleno. ${ }^{43}$

Hegel tento moment ještě podtrhuje tím, že totožnost nevztahuje jen k různosti, ale „čistotu“ obecných pojmů narušuje i tím, že je zasazuje do bezprostřední smyslové skutečnosti. Nejenže se stejnost bytostně vztahuje k jinakosti, oba rody či pojmy musí vstupovat do jevu, nebot' se teprve tím stávají skutečnými: Vše, co je, je jen, nakolik se to ukazuje. Zatímco tak první vývoj vnímání směřoval k pojmovému uzemnění „herakleitovského“ toku prostřednictvím „parmenidovské“ jednoty, nyní je vykonána i cesta zpět: Tyto pojmy musejí být „uzemněny“ smyslovou skutečností, v níž musejí dosvědčit svou patřičnost.

V tom př́ípadě spadají struktury bytí vjedno se strukturami jevení. Jevení však nikdy není jen jednotou: Již v Hegelově raném spisu, v tzv. Spisu o diferenci, čteme, že jevit se a rozdvojovat je jedním. ${ }^{44}$ Jev tak lze pochopit jako jednotu jen za předpokladu, že se na jednotě spolupodílí mnohost. Hegel tím již od svého jenského období formuluje - v sepětí s Platónovou dialektikou - ontologii, kterou bude následně rozvíjet ve všech svých spisech. Specifikem této ontologie pak je, že Hegel včleňuje dialektiku základních momentů identity a diference do smyslové skutečnosti, čímž dospívá k „objektivní“45 a „smyslové“ dialektice. Vnímající vědomí ve Fenomenologii ducha i později v Encyklopedii filosofických věd rozlišuje na předmětu dvě strany: Nejenže je předmět jednotou, ale vykazuje i mnohost „matérií", tedy vlastností, které přetrvávají „,vedle sebe“. Tento vhled vede vědomí k tomu, že na předmětu rozeznává odlišné ohledy, a začíná tak chápat, že vnímaný, ale i myšlený fenomén je nějakým způsobem podvojný: Je jednotným,

42 Viz především G. W. F. Hegel, Vorlesungen über die Geschichte der Philosophie, I, str. 289.

43 Platón, Soph. 245b.

44 G. W. F. Hegel, Differenz des Fichteschen und Schellingschen Systems der Philosophie, in: E. Moldenhauer-K. M. Michel (vyd.), Werkausgabe in 20 Bänden, II, Frankfurt a. M. 1969 nn., str. 206.

Toto hledisko neopouští ani v pozdním díle. Nadále mu za měřítko platí to, co se ukazuje v jevu: „Podstata se musí jevit. ... Podstata tedy není za jevem nebo vně jevu, nýbrž tím, že to, co existuje, je podstatou, je existence jevem.“ G. W. F. Hegel, Malá logika, přel. J. Loužil, Praha 1992, § 131.

$45 \mathrm{~K}$ tomu viz H.-G. Gadamer, Hegel und die antike Dialektik, str. 6. 
ale i mnohým (tj. vykazuje mnohé vlastnosti), a je jednotlivý, ale zároveň i obecný. ${ }^{46}$

Perspektivami, které vystihují podvojnost nejvyšších rodů, se zabývá i Platón v Sofistovi: Každá idea prochází růzností, ale nezávisle na tom si uchovává vlastní jednotu či svou bytnost. Poznání tohoto vztahu je v dialogu Sofistés označeno jako dialektika, a potud je dialektika uměním, „co do pojmu umět rozlišit, nakolik každé jednotlivé může být ve společenství a nakolik ne“. ${ }^{47}$ Toto jednotlivé je tedy - řečeno s Hegelem - soběrovné, a zároveň je ve společenství s růzností, a potud je různé, nikoli však v jednom a témže ohledu, ale z odlišných perspektiv.

Právě toto odlišení ohledů je však krok, který Hegel ze Sofisty nejen nepřijímá, ale zdá se dokonce, že zprvu tuto nauku ze Sofisty Platónovi ani nepřipisuje. Dialektické rozlišování ohledů totiž spojuje s dvěma nebezpečími, jichž se dopouštějí sofisté, antičtí i ti novověcí. Sofisticky si počíná ten, kdo nejprve rozliší ohledy, a následně jednu ze dvou nezbytných perspektiv povýší a druhou znehodnotí, přičemž je nejčastěji pozitivně vyzdvižena jednota, zatímco mnohost či rozdílnost je považována za nebytostnou. ${ }^{48}$ Další důvod, proč Hegel ,zřetelovou ontologii“ odmítá, souvisí s problémem věci o sobě, kterou Hegel pojímá jako postulát vynucený perspektivismem. Vyjdeme-li z odlišování perspektiv, snadno sklouzneme k mylnému přesvědčení, že se pravé věci dobereme „odečtením“ našich perspektiv, tím, že uchopíme věc v její čistotě.

Hegel vposled nazývá právě tuto „zřetelovou ontologii““ sofistikou a v Logice jako vědě pak čteme:

„Nebot' sofistika je rozumování z bezdůvodného předpokladu, který považujeme za platný, aniž bychom jej podrobili kritice či blíže prozkoumali; naopak dialektikou nazýváme vyšší rozumový pohyb, jímž se takovéto naprosto odlišně se jevící momenty v sobě samých a v tom, čím jsou, proplétají, a předpoklad [jejich odlišenosti] je tím překonán. V dialektické imanentní povaze bytí a nicoty samé tkví, že vyjevují jednotu, nastávání jako svou pravdu. “49

46 G. W. F. Hegel, Fenomenologie ducha, str. 121 nn. Srv. paralelní pasáže v Enzyklopädie der philosophischen Wissenschaften, § 420-422.

47 Platón, Soph. 253e.

48 G. W. F. Hegel, Fenomenologie ducha, str. 121.

49 G. W. F. Hegel, Wissenschaft der Logik, I, str. 111. 
Podstatné je, že proměnlivost a dynamičnost, které jsou připisovány ve „zřetelové ontologii“" perspektivám, tedy výkonu vnímajícího, jsou součástí jevu samého. Takto pojatá ontologie přitom není jen zvláštností Hegelova díla, ale rovněž Hegelovy interpretace Platónova Sofisty. Hegel tak přisuzuje Platónovi stanovisko, podle něhož se samy rody navzájem „myslí“ a samy sebe zahrnují. Jinakost tak nestojí vedle stejnosti, ale stejnost je jinakostí na sobě samé, resp. jinakost je sama principem stejnosti. Hegel navíc umist’uje toto „dění“ již do smyslové skutečnosti: Každá vlastnost předmětu se tímto způsobem vztahuje ke své vlastní jinakosti, resp. svou identitu konstituuje ve vztahu k tomu, čím není. Zdroj smysluplnosti tím pro Hegela tkví již v předmětné skutečnosti: Jako vnímané a jako myšlené se jevy konstituují ve svém vztahu k jinakosti, a vnímající je tak již vždy stržen tímto dějem, od něhož se sám musí odlišovat, tedy svou vlastní negativitou vymezovat, čímž však zároveň stvrzuje prŕslušnost ke světu, nezávisle na němž by se nemohl určit. ${ }^{50}$

Co však vedlo Hegela k tomu, že Platónovi připsal podobné pojetí? Již během svého jenského období považuje Hegel dialog Sofistés za svědectví toho, že Platón usiloval o uchopení myšlení jako pohybu. Hegela zaujala především pasáž, v níž se mimo jiné říká, že filosof má

„býti schopen sledovat výklady s posuzováním každé myšlenky, kdykoli někdo o různém tvrdí, že to je v jistém smyslu totéž, i kdykoli tvrdí o tomtéž, že to je různé, tím způsobem a hledíc $\mathrm{k}$ tomu, co se podle toho tvrzení s tím i oním děje“. 51

Je příznačné, že Hegel přeložil stěžejní část pasáže následovně: Filosof má býti schopen sledovat, že

„to, co je různé, je totéž, a co je totéž, je různé, a to v jednom a témže ohledu“. 52

50 Viz např. G. W. F. Hegel, Fenomenologie ducha, str. 106.

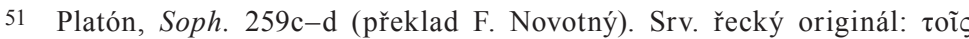

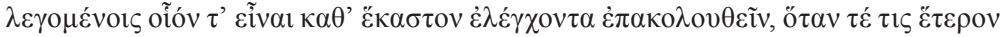

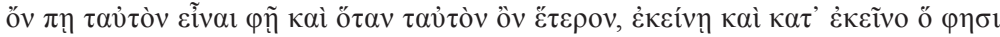

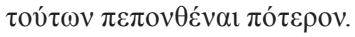

52 G. W. F. Hegel, Vorlesungen über die Geschichte der Philosophie, II, in: E. Moldenhauer - K. M. Michel (vyd.), Werke, XIX, Frankfurt a. M. 1969, str. 72. Hegelův překlad se ozřejmí, srovnáme-li ho s Ficinovým latinským překladem, s nímž Hegel pracoval: ... sive quod alterum est, idem, sive quod idem, alterum, atque id eadem utrumque ratione esse convincens. 
Na překladatelskou chybu upozornil již v Hegelově době C. L. W. Heyder. ${ }^{53}$ Zjevné však je nejen to, že se jedná o překladatelskou chybu, ale že překlad posouvá sám dialog směrem k Hegelovu vlastnímu pojetí dialektiky a ontologie, která se výraznou měrou dotváří právě na pozadí Sofisty. Vycházeje ze svého překladu dialogu přisuzuje Hegel Platónovi pozici, dle které zahrnují samy nejvyšší rody v sobě samých svůj protiklad: Každý nejvyšší rod si je sám na sobě růzností tím, že se bytostně vztahuje $\mathrm{k}$ tomu, čím není, čímž tuto různost včleňuje do sebe sama. Každá idea tak je tím, čím je, jen díky tomu, že podléhá různosti, a díky tomu, že je neustále ohrožena zánikem v různosti.

Platón však trval na tom, že každý rod disponuje svou vlastní fysis, která není prostoupena růzností. ${ }^{54}$ Jednotlivé rody se sice vztahují k rodům totožnosti a různosti, ale rozhodující je právě ono odlišení perspektiv: Věc je z jednoho hlediska totožná, z jiného různá, a rod tak vykazuje na straně jedné totožnost, nakolik se jedná o jeden určitý rod, a zároveň na straně druhé participuje na různosti, nakolik je různý od ostatních. Díky odlišení zřetelů se Platón vyvaroval kladení sporu. ${ }^{55}$

\section{Spornost v jevu}

Naopak Hegel činí určitý typ spornosti středobodem své ontologie. Ve Fenomenologii ducha, ale např́klad i v jenském raném textu, tzv. Stati o skepticismu, jednoznačně vyzývá, aby myslitelé na spor přistoupili:

53 C. L. W. Heyder, Kritische Darstellung und Vergleichung der Methode Aristotelischer und Hegelscher Dialektik, I, Erlangen 1845, str. 99 nn. Klaus Düsing, Dialektikmodelle. Platons Sophistes sowie Hegels und Heideggers Umdeutungen, in: týž, Aufhebung der Tradition im dialektischen Denken. Untersuchungen zu Hegels Logik, Ethik und Ästhetik, München 2012, str. 77-92.

54 Pavel Kouba rovněž „,poopravuje“ vyznění Platónova Sofisty - a v tomto ohledu podobně jako Hegel: „Nestačí proto s Platónem uznat, že jsoucí může vstoupit do svazku ( $\sigma \nu \mu \pi \lambda$ oкฑ́) s ne-jsoucím: je třeba nahlédnout, že jsoucno z tohoto svazku nemůže vystoupit, nemá-li přestat být.“ A dále zde čteme: „Považujeme-li identitu za stejně původní se vztahem k různému, je zřejmé, že výkon individuálního bytí sebou je také ohrožen dvojím zpo̊sobem: nejen ztrátou identity, nýbrž také její izolací a uzavřením v ní.“ P. Kouba, Bytí nejsoucna v Sofistovi, in: Reflexe, 37, 2009, str. 101-113, zde: 104, 123. Žádný důvod k „opravám“ nevidí H.-G. Gadamer, který přiznává, že se Hegel dopustil překladatelské chyby, ihned však dodává, že Hegel sleduje velmi správně intenci či ducha textu. Srv. H.-G. Gadamer, Hegel und die antike Dialektik, str. 3-28.

55 Zákon sporu je v dialogu formulován na několika místech. Viz např. Platón, Soph. 230b, $263 \mathrm{~d}$. 
„Co je nyní nutno mysliti, je čistá střída čili protiklad $v$ sobě samém, spor. "56 Podle mnohých kritiků je toto jedním z Hegelových základních prohřešků vůbec. ${ }^{57}$ Dříve než budeme s to Hegelovo přitakání sporu posoudit, je třeba se blíže zaměřit na to, co jím Hegel míní.

Závazek k respektování principu sporu jako pravidla, jímž se řídí naše myšlení, implikuje podle Hegela specifickou ontologii. Vyjdeme-li z principu sporu, předpokládáme předmět jako substrát, ${ }^{58}$ na nějž jsou zvnějšku „připevňovány“ vlastnosti, resp. pracujeme s metaforou ,inherence“: Pakliže předmět v sobě již „obsahuje“ vlastnost „přítomnost bílé“", nelze mu připsat vlastnost „,nepřítomnost bílé“.

Podle Hegela je však třeba spor pojmout nikoli jako vztah bytí a nebytí, prítomnosti a nepřítomnosti, ale jako vztah odlišných vlastností. ${ }^{59}$ Je zjevné, že Hegel tím oslabuje, či dokonce redefinuje pojem sporu,

56 G. W. F. Hegel, Fenomenologie ducha, str. 141. Srv. rovněž G. W. F. Hegel, Verhältnis des Skeptizismus zur Philosophie. Darstellung seiner verschiedenen Modifikationen und Vergleichung des neuesten mit dem alten, str. 230. V Logice jako vědě pak zaznívá věta: „Všechny věci jsou na sobě samých v sobě sporné.“Viz G. W. F. Hegel, Wissenschaft der Logik, II, str. 74.

57 Viz napr. B. Russell, Logic as the Essence of Philosophy, in: I. M. Copi J. A. Gould (vyd.), Readings on Logic, New York 1972, str. 78. Komentár k tomu problému ve vztahu k Russellovi nabízí R. Pippin, Hegel's Metaphysics and the Problem of Contradiction, in: J. Stewart, The Hegel Myths and Legends, Evanston (I1l.) 1996, str. 239-252. Srv. k tomu rovněž R. Pippin, Die Logik der Negation bei Hegel, in: týž, Die Aktualität des Deutschen Idealismus, Frankfurt a. M. 2015, str. 191-219. Velmi vstřícné čtení Hegelova pojetí sporu nabízí Theodor Adorno, který vztahuje vnitřní spornost každého předmětu k Hegelovu objevu historičnosti: Tím, že jsou i neživé předměty součástí lidské skutečnosti, která se odvíjí v dějinách, náleží i jim ,časové jádro“. Hegel tak vychází z „bytostné dynamičnosti věci samé, jinými slovy: z bytostné dějinnosti světa vůbec - vyjadřuje bytostnou zkušenost, že mezi nebem a zemí neexistuje nic prostě jen tak, že vše, co je, je vlastně dynamické, a že je tudíž třeba pojmout vše, co je, jako cosi, co nastává“. Th. Adorno, Einführung in die Dialektik (1958), Frankfurt a. M. 2015, str. 20.

58 V této souvislosti poznamená D. Henrich, že Hegelovi nešlo např. v kritice Kanta o jeho epistemologii, ale o ontologii, kterou chápal jako ontologii jednotlivých věcí. Viz D. Henrich, Kant und Hegel, str. 192-196.

59 „Bude-li následně řeč o negativitě či o negativní přirozenosti, pak tím není míněna ona první negace, hranice, mez nebo nedostatek, ale podstatně negace jinobytí, která je v této podobě vztahem k sobě samé.“ G. W. F. Hegel, Wissenschaft der Logik: Die objektive Logik (1812-1813), in: Gesammelte Werke, XI, Hamburg 1978, str. 77 (Hegelova kurziva). Nutno podotknout, že právě takovou redefinici „nebyti““ na „býti odlišný od“ provedl i Platón v Sofistovi: Nebytí není protiklad bytí ve smyslu jeho negace, nýbrž odlišnost od něčeho jiného. Viz Platón, Soph. 257b3c3. Vztahu Hegelova pojetí sporu a ontologie se v tomto smyslu věnuje Michael Wolff (Der Begriff des Widerspruchs. Eine Studie zur Dialektik Kants und Hegels, 
a potud je matoucí, vyzývá-li k jeho kladení, čímž se opírá o úzus běžný v dané době. Hegel však nově definuje rovněž pojem věci: Ta již není jsoucnem nezávislým na našem vnímání či myšlení - věc je jen, pokud se nám ukazuje, tedy pokud je jevem. Naše vnímání a myšlení vstupuje do věci samé, aniž by však věc byla na náš výkon redukovatelná. Býti jevem navíc patří $\mathrm{k}$ bytostnému určení věci, a bytnost tak můžeme odhalit jen tím, že přistoupíme na to, že se v jevu jeví bytnost sama, či dokonce že jev sám je bytností.

Odlišné uchopení sporu je tak vposled motivováno ontologií, kterou Hegel připisuje novověkým filosofům a s níž se chce kriticky vyrovnat. Proti ontologii věcí a vlastností klade Hegel jakousi „transcendentální“ nebo jevovou „ontologii“, do níž vždy vstupuje akt myšlení: Věc jakožto myšlená nesestává ze substrátu, jemuž by byly připsány vlastnosti; a dále skutečnost, že nemůžeme věc koncipovat nezávisle na prostředí, na jehož pozadí se nám ukazuje, je tedy pro ni samu bytostná. Jednotlivé vlastnosti lze uchopit jen na pozadí toho, čím nejsou: Bělost soli tak vnímáme na pozadí naší zkušenosti s barevným spektrem a krychlovost na pozadí jejího vztahu k ostatním tvarům. Každé určité bytí je tak výsekem z celku, kterým je jev nesen. V tomto smyslu pak Hegel tvrdí, že věc není pevným substrátem, ale „vnitřním rozdílem“:60 je kontrastem, neboli vyžaduje prostředí, vůči němuž se vyjímá, z něhož se vymezuje a které v tomto smyslu neguje, a tím paradoxně ale i zpř́ítomňuje.

$\mathrm{Z}$ toho jsou patrné dvě okolnosti: Jsoucno je pro Hegela vždy bytostně určené jako jev - věc je vždy pro nás, tedy je určená jako jsoucno vnímané a myšlené. A myšlení, resp. vědomí vůbec, se vyvíjí skrze tento typ ,spornosti“, tedy skrze vztah stejnosti a jinakosti. V tomto smyslu není Hegelova fenomenologie či logika jevu pouhým průchozím bodem na cestě k logice věcí, tak jak jsou o sobě. Je sice pravda, že se v jevu vždy jeví něco více než výhradně jev, nejedná se ale o věc o sobě, která by jevem ,prosvítala“. Věc je spíše jevem v tom smyslu, že odkazuje na svůj vlastní přesah a v tomto smyslu je určena jako jev konečný a závislý na tom, čím sám není, tedy na souvislosti, v níž se jeví.

Tím vstupuje do hry další okolnost: Hegelovo pojetí jsoucna jakožto jevu uprostřed souvislosti vyplývá z jeho holisticky uchopené skutečnosti - aby vědomí cokoli vnímalo či myslelo, zkrátka aby mohlo cokoli

Frankfurt a. M. 2010). Wolffově knize se podrobně věnuje R. Pippin in: Die Logik der Negation bei Hegel, str. 191-219.

60 G. W. F. Hegel, Fenomenologie ducha, str. 142. Srv. paralelní pasáže v Enzyklopädie der philosophischen Wissenschaften, III, § 423, str. 211. 
pro vědomí být, musí vnímat a myslet implicitně vždy více, než je mu tematicky př́tomno. Fenomenologie ducha pak usiluje o rozkrytí celého pole, na němž vědomí může vnímat jednotlivá jsoucna.

Na tomto pozadí lze lépe porozumět Hegelově výzvě, abychom spor mysleli „méně povrchně““. ${ }^{61}$ Hegel nehovoří o tom, že by bylo třeba přistoupit na spor v tom smyslu, že budeme připisovat předmětu vlastnost, kterou mu ve stejném ohledu odepřeme. Určitou podobu sporu však klade na ontologickou rovinu jsoucna. V tomto případě se však nejedná o připisování $\mathrm{v}$ jednom a témže smyslu konkrétnímu předmětu vlastnost i její negaci, ale o připisování konkrétní vlastnosti a její jinakosti - a to skutečně v jednom a témže ohledu. Při tomto připisování přitom postihujeme cosi na věci samé - proto hovoří Hegel o sporu nikoli v subjektivní, ale v objektivní logice.

To je rovněž důvod, proč je Hegel přesvědčen, že se nemůžeme - navážeme-li na Platónova Sofistu - spokojit s tvrzením, že je něco z určitého hlediska týmž, z jiného jiným. Místo toho je třeba připustit niterné zřetězení jednotlivých rodů. Zdá se, že i Platón hovoří o takovémto zřetězení, když nejvyšší rody pojímá jako „společenství“, dokonce rríká,

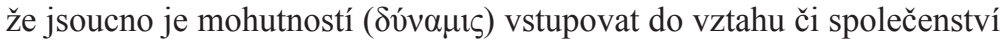

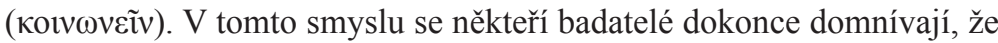

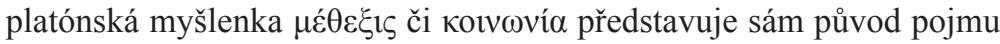
hegelovského zprostředkování, tedy nejzákladnějšího principu Hegelovy filosofie vủbec. ${ }^{62}$

Ukázali jsme, že Hegel z Platóna skutečně čerpal, ale „společenstvi““ je pro něho prŕliš slabým určením, nebot' se nadále předpokládá, že rod má svou bytnost, která je nezávislá na ostatních rodech: Rody jsou usouvztažněny, nejsou ale propojeny. Hegel v této souvislosti žádá, abychom připustili, že diference prostupuje identity každého fenoménu ještě podstatněji: Vyjdeme-li ze „smyslových“ rodů z Platónova Sofisty, můžeme tvrdit, že pohyb neexistuje jen na rozdíl od klidu, ale bytostně dikky klidu a jeho prostřednictvím; a užijeme-li Hegelův př́klad, pak sladké neexistuje na rozdíl od kyselého, ale v sepětí s kyselým. ${ }^{63}$

61 G. W. F. Hegel, Fenomenologie ducha, str. 140.

$62 \mathrm{~K}$ tomu viz např. W. Becker, Hegels Begriff der Dialektik und das Prinzip des Idealismus. Zur systematischen Kritik der logischen und der phänomenologischen Dialektik, Stuttgart - Berlin - Köln 1969, str. 44 n.

63 G. W. F. Hegel, Fenomenologie ducha, str. 138-140. V Logice jako vědě pak Hegel poznamenává, že všechny přirozenosti vystupují ze své „nevinnosti“ (tj. identity) a skrze sebe sama se vztahují k jinému, a věci jsou tak v sobě samých „zlomené“. Viz G. W. F. Hegel, Wissenschaft der Logik, II, str. 72, 79. 
Hegel tím připisuje nejenom nejvyšším rodům tuto „vnitřní rozervanost", ale i každému jsoucnu, které je proto určeno jako jsoucno konečné. V tomto smyslu je každé jsoucno mohutností být sebou samým; tuto mohutnost však osvědčuje proti jinakosti, která není jen jeho vnějším prostředím, ale která je rovněž jeho niternou jinakostí - a díky tomuto „vnitřnímu rozdílu“64 je každé jsoucno schopno nejen zůstávat stejným, ale rovněž se stávat jiným.

Z výroků z pozdního berlínského období vyplývá, že si Hegel uvědomil určitou nepatřičnost své interpretace Sofisty. Hegelovi se nyní jeví Platónova filosofie jako „sofistická“, zatímco jeho vlastní jako „spekulativní“ ${ }^{65}$ Sofistická dialektika spočívá právě ve zmíněné „zřetelové ontologii““. Podle Platóna jsou jednotlivé rody se sebou samými totožné, což umožňuje jejich myslitelnost. Pohybu se účastní jen potud, pokud jsou předmětem myšlení. Z tohoto hlediska by „eleatská pozice“ v dialogu Sofistés nebyla překonána, ale na vyšší úrovni reprodukována, a to proto, že vlastnosti samy nejsou myšleny jako výkon bytí, ale jako soběrovné rody, jejichž identita je nadřazena jejich vztahu k různosti. ${ }^{66}$

Proti tomu Hegel poznamenává: Každá vlastnost existuje, jen nakolik se udržuje v přesahujícím kontextu a tento přesah do sebe reflektuje nebo pokud jednotlivé rody reprodukují rozlišení nitra a vnějšku, resp. vlastního a cizího ve svém nitru. Vztah k vlastní jinakosti spadá vjedno s existencí dané vlastnosti, a potud vykonává každý fenomén základní strukturu absolutna, kterou Hegel určuje již od svého raného díla jako „identitu identity a ne-identity“, tedy jako výkon usouvztažňování totožnosti a různosti: ${ }^{67}$ Vše, co vznáší nárok na bytí, ztělesňuje identitu identity a ne-identity neboli každý fenomén je vnitřním rozdílem. Každý fenomén si tak odpovídá jen tím, že si odporuje, resp. tím, že se vztahuje k sobě vlastní jinakosti, a tak se klade jako ten, který není jiným, což pro Hegela právě znamená, že jiným do značné míry je: Má-li se od jinakosti distancovat, musí se k ní vztáhnout - a to znamená, že ji činí momentem sebe samého, že sám rozdmýchává spor uvnitř svého vlastního bytí. ${ }^{68}$

64 Viz G. W. F. Hegel, Fenomenologie ducha, str. 141. G. W. F. Hegel, Enzyklopädie der philosophischen Wissenschaften, III, § 423, str. 211.

$65 \mathrm{~K}$ tomu viz rovněž Nürnberger und Heidelberger Schriften (1808-1817), in: Werke, IV, str. 415.

66 G. W. F. Hegel, Wissenschaft der Logik, I, str. 111.

67 Viz G. W. F. Hegel, Differenz des Fichteschen und Schellingschen Systems der Philosophie, str. 96.

68 G. W. F. Hegel, Fenomenologie ducha, str. 140. 
Hegelova ontologie a z ní vyplývající pojetí sporu či jinakosti jsou tak spjaty s holistickou koncepcí skutečnosti, kterou Hegel klade proti pojetí skutečnosti jako sumy předmětů, jímž se podle něj do určité míry provinili i „subjektivní idealisté“. Toto provinění snad ani primárně nespočívá v tom, že si v této koncepci představujeme bytí jako věc, a nikoli jako proces. Hlavní prohřešek lze nakonec shledat $v$ tom, že je identita ontologicky nadřazena diferenci. Hegela můžeme v tomto smyslu považovat za prvního myslitele, který důsledně na všech úrovních Kantových tř́ základních filosofických otázek předložil holistickou koncepci skutečnosti, tedy koncepci, která je odkázána na diferencující dynamiku.

Nutno ovšem poznamenat, že tato koncepce je zatížena obtížemi, jimž se Hegelem kritizovaný Platón byl schopen vyhnout: Zdá se, že to byl právě Platón, který pečlivěji a důsledněji rozlišoval opak na straně jedné, a odlišnost či jinakost na straně druhé. ${ }^{69}$ Dalším problémem je skutečnost, že i Hegel, který vychází ze vztahu stejnosti a jinakosti, musí původně předpokládat základní, snad i substanciální odlišnost těchto dvou bytostných momentů skutečnosti. ${ }^{70}$ Právě tomu se však Hegel brání: Stejnost je stejností ve vztahu k jinakosti, čímž se sama stejnost zjinačuje. Má-li však mít smysl hovořit o stejnosti a jinakosti, pak se právě za předpokladu, že přijmeme vztaženost těchto dvou momentů, vposled bud' musíme oprrít o Hegelem kritizovaná hlediska: identita a diference jsou pak dvě strany jedné mince, anebo dokonce musíme předpokládat, že tyto dva základní hybné momenty stojí vně souvislosti, vně přediva vztahů, jímž skutečnost vposled je. Bez této základní odlišnosti bychom stěží získali vztah: Má-li se určené jsoucno ve své určenosti „udržet“ a „uchovat“, musí být již vždy pozitivně určené - jinak by nemělo co uchovávat.

Ale nezávisle na tomto problému se rýsuje jedno poněkud překvapivé zjištění: Myslitel, jehož filosofie je považována za ztělesnění monistické koncepce, je spíše myslitelem „ontologického vztahu“, a to vztahu postaveného na identitě a diferenci, resp. na pozitivitě a negativitě. $V$ tomto

69 O tom svědčí již okolnost, že Hegel pojímá vztah pohybu a klidu primárně jako vztah „smyslových“ rodů, jejichž existence poukazuje k uplatnitelnosti nejvyšších rodů ve smyslové skutečnosti. Sám Platón však díky dvojici klidu a pohybu formuluje vztah kontradikčnosti a díky dvojici totožnosti a různosti vztah kontrárnosti.

70 Kritice různých typů filosofických koncepcí spočívajících na korelaci se věnuje Wolfgang Cramer (Das Absolute und das Kontingente, Frankfurt a. M. 1976², zejm. str. 68-74). 
smyslu by Hegelovi měl motiv platónské symploké nepochybně konvenovat, sám však zdůrazňuje, že nejen celek spočívá na vztazích, ale právě i jeho část. Hegelova koncepce skutečnosti tedy není v základu monistickou jednotou, ale předivem vztahů spočívajícím na určitém typu dualismu, který bychom snad mohli spolu s Wolfgangem Cramerem nazvat vztahem ,pramomentů dialektického rozvinutí““. ${ }^{71}$ Propletení dualistických a monistických prvků se vine napřič veškerým filosofickým tázáním - a v jednotlivých otázkách předkládá Hegel koncepci, která se jeví jako „dualističtějšśi“ než koncepce, jež jsou tradičně za dualistické považovány. Pojmeme-li jako projev dualismu Platónovu koncepci dvou světů nebo vztah těla a duše, pak můžeme s jistým oprávněním tvrdit, že Hegel předkládá hlubší dualismus. Přítomný smyslový svět není ontologicky podřízen světu idejí a tělo není ontologicky podřazeno duši, což ale neznamená, že by byly jednotou: Jsou spolu, protože se na sobě „profiluji““. Hegel tak vposled dociluje toho, že dualismy povstávají ve zvláště výrazných obrysech: procházejí napříč světem i člověkem.

\section{Závěr}

Negativita není vlastností či mohutností, kterou by se vyznačovalo výlučně vědomí nebo subjektivní rozum: Protože se celý svět vyjevuje jako svět pro vědomí, nejeví se žádný předmět nezávisle na negativitě. Negativita potom není ničím, čím by se vědomí distancovalo od světa a díky čemu by se vztahovalo k sobě samému: Je fenoménem ve světě, ${ }^{72}$ a pro Hegela také prostředníkem mezi sebevědomím a světem - negace vytváří silnější pouto než pozitivita, kterou Hegel napříč svým dílem spojuje s nevědomostí či nedostatečnou reflektovaností. To je nakonec i důvod, proč lze Fenomenologii ducha číst jako řadu konfliktů (spíše než jako epos smíření) - at' už na úrovni bytí anebo později především na úrovni lidských vztahů.

S negativitou je spjato bytostné znejistění všeho jsoucího. Právě toto rozkolísání, které je principem živoucnosti, označuje Hegel výrazem dialektika, ale i „skepticismus“. ${ }^{73}$ Lidské vědomí se vyznačuje snahou

\footnotetext{
71 Srv. tamt., str. 78.

72 K tomu viz G. W. F. Hegel, Nürnberger und Heidelberger Schriften, str. 434.

73 Hegel poznamenává v Encyklopedii filosofických věd, že skepticismus integrovaný do filosofie je dialektikou, ale filosofie překračuje takto pojatou dialektiku jako metodu, a tím se stává spekulací. Viz G. W. F. Hegel, Enzyklopädie der philosophischen Wissenschaften, I, § 81, dodatek 2, str. 175 n.
} 
vymknout se této situaci a ustavit se ve své jednotě. Tento postoj je však základním omylem - dokonce zlem - sebevědomí. Bytí a jeho poznávání tkví v „naplňujícím se skepticismu“ , ${ }^{74}$ který nemá být „,naplněn“ absolutní jistotou, at' už by se jednalo o nezpochybnitelný fakt vědomí či absolutní Já. Takovéto ,jednoznačnosti“ či „hotové pravdy“75 sice činí zadost skeptické otázce, ale důsledkem je, že zároveň samu otázku, v jejímž napětí veškeré bytí spočívá a díky níž náleží každému jsoucnu vždy možnost být něčím jiným, ničí. Napětí této otázky je život jevu, z něhož jediného vychází bytí jako bytí určité. Úkolem spekulace je tuto otázku, v které dané jsoucno tkví, vystihnout, nikoli na ni podat odpověd'.

Dialektika ve svém ontologickém určení není pouhou metodou, ale je sama principem skutečnosti, tedy cílem poznání. Jakmile vědomí toto nahlédne, zaujme spekulativní stanovisko, nebot' dialektická určení pak připisuje skutečnosti samé. Dialektika se tím mění ve spekulaci, a potud není pojata jako pouhá metoda dopravující ,„pocestného“ $\mathrm{k}$ cíli, který na něj čeká na konci a který je této cestě samé vnější. Jedině na této cestě dospíváme k náhledu, že sama skutečnost je dialektická a že dialektika reflektuje či zrcadlí bytí samo.

\section{ZUSAMMENFASSUNG}

Der Beitrag befasst sich mit Hegels Dialektik vor dem Hintergrund von Platons Sophistes. Hegel radikalisiert die Lehre von den höchsten Gattungen, indem er diesen Einheitlichkeit ausschließlich in Bezug auf Andersheit zuschreibt, wobei dieser Bezug nicht an Hinsichten gebunden ist, sondern ontologisch begründet ist. Einheit konstituiert sich durch die Differenz. Diese Dynamisierung vom Sein ist vor dem phänomenologischen Hintergrund der Philosophie Hegels zu deuten: Sein ist nur insofern, als es erscheint, und als erscheinendes ist es Bezug. Eher als ein monistischer Philosoph wäre Hegel somit als Philosoph des ontologischen Bezugs aufzufassen.

74 K této souvislosti viz F. Duque, Die Selbstverleugnung des Endlichen als Realisierung des Begriffs, in: H. F. Fulda - R.-P. Horstmann (vyd.), Skeptizismus und spekulatives Denken in der Philosophie Hegels, Stuttgart 1966, str. 135-176.

75 G. W. F. Hegel, Fenomenologie ducha, str. 87. 
The article focuses on Hegel's conception of dialectics against the background of Plato's The Sophist. Hegel radicalizes Plato's doctrine of the highest genera by understanding unity exclusively as related to alterity. Instead of being tied to perspectives, this relation is ontologically grounded - unity is constituted through difference. This dynamic conception of being is then understood against the background of Hegel's Phenomenology: any being is only insofar as it appears; and as appearing it is essentially a relation of sameness and alterity. Rather than a monistic philosopher, Hegel is to be understood as a thinker of the ontological link between unity and difference. 